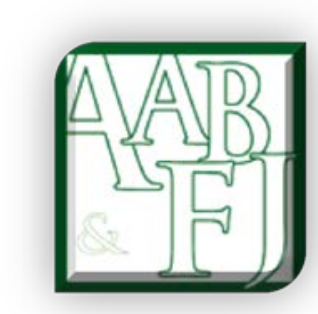

\title{
The Roles of Size and Size Difference in Australian and Chinese Inter-firm Collaborations
}

\author{
Yu Zhang ${ }^{1}$, Zhiming Cheng \& Charles Harvie
}

\begin{abstract}
There has been considerable debate on the contribution and significance of firm size to the establishment, operation and success of business collaboration. One important source of this debate arises from differing definitions of firm size used in previous research. This paper uses firm size categories and size differences between collaborating firms to examine their contribution to the formation and performance of inter-firm collaboration in Australia and China. Both qualitative case study and quantitative data analyses are adopted in this paper.

Results from both the qualitative case study and quantitative study in Australia and China show that size plays a significant positive role in the formation and performance of business collaboration. Firms prefer collaborating with larger partners. Bigger firms are more likely to achieve success collaborations. However, size difference plays a negative role in business collaboration. Collaborating with a bigger partner makes it harder to succeed. On the other hand, size and size difference play very different roles in performance and outcomes of business collaboration in different countries.

This paper compares the roles of firm size and size difference in Australian and Chinese inter-firm collaboration. The results provide important strategic implications for business managers, industry regulators, and policy decision makers regarding international business collaboration.
\end{abstract}

Keywords: Collaboration, Size, Size Difference

JEL Codes: L25 and M20

\footnotetext{
1 University of Wollongong

Email:azhang@uow.edu.au
} 


\section{Introduction}

Many empirical studies have tried to link firm size with the performance and outcomes from business collaboration (Hagedoorn and Schakenraad, 1994, Teece, 1986). However, there is still considerable ongoing debate on this issue. The use of differing definitions of firm size is one of the causes of this debate (Zhang, 2012). Most previous studies have focused on developed countries such as the U.S., Japan and some European countries. However, with the fast development of some developing countries, such as China, business collaboration between developed countries and developing countries has increased dramatically in recent years. This development has contributed to both domestic and global economic growth, and has attracted the interest of researchers from management, business studies, economics and the social sciences. Therefore, to address the gap in the existing literature this study compares differences between Australian and Chinese business collaboration and the influence of firm size on its performance.

Previous research on this issue has mostly employed the same definition of firm size across countries, putting firms with different policy and financial support into the same category. Definitions of firm size are different across countries and even across industries in the same country. Therefore, instead of using firm size based upon employee numbers and sales value as in previous literature, this paper uses size categories (as defined officially in Australia and China) and size difference between these categories to examine their influence on the performance of inter-firm collaboration. To identify the contribution of firm size and size difference in business collaboration, this paper adopts both qualitative face-to-face interviews and quantitative regression analysis for more than 300 firms in the telecommunication and related industries in Australia and China. The results are expected to provide important strategic lessons and implications for business managers, industry regulators, and policy decision makers regarding international business collaboration.

The paper proceeds as follows. The second section conducts a review of the literature. The methodologies adopted as well as key research questions addressed in this paper are presented in the third section. Data collection and sample size and characteristics are outlined in the fourth section. The qualitative and quantitative results from this study are presented and analysed in the fifth section. The final section concludes with a summary of the major findings from this study.

\section{Literature Review}

\section{Business Collaboration and Strategic Alliances}

Focusing on the real costs of firms' operations and transactions, transaction cost theory (Coase, 1937) explains the incentives and reasons for inter-firm collaboration as well as for the existence of firms. The resource based view (Barney, 2001, Das and Teng, 1998, Rumelt, 1984) focuses on the scarce resources that are inimitable or cannot be substituted to sustain and increase a firm's development and collaboration. Transaction cost theory opened the door for the study of firms and also contributed to the development of the resource based view (Teece, 1982). The resource based view contributed to the study of business collaboration by distinguishing between tangible and intangible resources (Barney, 2001) and shed light on the dynamics of collaboration (Das and Teng, 1998, Rumelt, 1991). Based on the resource based view the knowledge based view of 
the firm also provides promising insights to extend our understanding of cooperation capabilities (Porter, 1990). Tallman (2000) linked the resource-based view with transaction cost theory and argued that collaboration provides firms with complementary capabilities. Papadopoulos, Cimon and Hebert (2008, p.152) indicated that transaction cost theory best explains "alliances in high asymmetry and low heterogeneity situations" " and the resource based view is "most appropriate for high heterogeneity and low asymmetry alliances"33.

\section{Firm Size and Business Collaboration}

The size of a firm affects its capability, scope, process, structure, regulations, behaviour and decision making. Large sized firms are likely to possess more specialised assets, business networks, patents and skilled labour (Hagedoorn and Schakenraad, 1994, Teece, 1986) and, therefore, are more engaged in building strategic alliances than their smaller competitors (Hagedoorn, 1995b). Small sized firms, on the other hand, usually suffer from lack of resources, lack of technology, lack of access to finance and lack of skilled labour (Chung et al., 2006, Harvie and Lee, 2003, Jaouen and Gundolf, 2007). Many researchers have argued that firm size plays an important role in the partnership formation process and in collaborating behaviour (Agardi, 2008, Berg et al., 1982, Burgers et al., 1993). For example, Felzensztein and Gimmon (2007) found that small firms in the salmon farming industry in Scotland are more active in building inter-firm collaboration. Shan and Hamilton (1991) found in their empirical research that small firms are more likely to cooperate than large firms. However, other researchers have argued that firm size contributes little to business collaboration (Oxley, 1997, Park and Ungson, 1997).

When it comes to the contribution of firm size to collaboration performance there are also diverging results in the literature (Zhang, 2012). Some researchers believe that similar firm size beneficially affects the performance of business collaboration because of similarities in capabilities, scope and processes faced by the partners (Chandler, 1962, Rumelt, 1974, Porter, 1987, Teece, 1977). Others believe that firm size does not significantly influence the formation and performance of alliances (Hagedoorn and Schakenraad, 1994, Oxley, 1997, Park and Ungson, 1997). Saxton (1997) argued that similarities between partners are negatively related to alliance outcomes and initial satisfaction. Chung et al. (2006) also argue that small firms may perform better in business collaborations than large firms. One reason for these different outcomes is the different definition of firm size used in these empirical studies.

\section{Definition of Firm Size Used in this Study}

Firm size in empirical studies is usually defined in terms of a firm's assets, sales revenue, turnover, or the average worldwide employee numbers of a firm. However, these definitions are usually used in developed countries and are only suitable for medium or large sized enterprises (Zhang, 2012). One empirical problem is that the majority of micro and small firms (usually more than $80 \%$ of total firms in most countries) are omitted from these studies. First, most small firms do not produce annual reports and they are reluctant to give their actual sales amount and annual turnover, a fact that is revealed by interviewees from the qualitative case studies conducted in this research. Second, firm assets, average sales and turnover are very different in

\footnotetext{
${ }^{2}$ Equity collaboration types such as equity joint ventures

${ }^{3}$ Non-equity cooperation in exploration, research and co-production
} 
different industries and countries, which make them inaccurate indicators of firm size. Third, the sales amount and turnover are also part of the performance measures of inter-firm collaboration. If firm size is measured by sales value, there will be an interaction between firm size and its performance as firm size affects its capability and resources (Teece, 1986). Therefore, the research results will be less reliable in this situation.

The official definition of firm size is different in different countries and even different industries in the same country (e.g. agriculture and service industries in Australia) (Zhang, 2012). If the same definition is adopted in a cross national study the "same sized" firms will have access to different government services, industry support programs, human resources, market information, bank loans and even pay different tax rates. How can these firms be regarded as peer-sized firms in an empirical study? Therefore, some researchers have used size difference to study its influence on the performance of business alliances (Gulati, 1995a, Saxton, 1997). ${ }^{4}$ However, the importance of size difference has not received systematic investigation in the literature.

Focusing on the Australian and Chinese telecommunication and related industries, this paper adopts the official definition of firm size used in Australia and China (for these industries) and uses different size categories to study their influence on the performance of business collaboration. Size difference between these categories is also used to identify its contribution to the performance of business collaboration. Separate empirical results are also presented for Australia and China to compare the key differences between these two countries.

\section{Australian and Chinese Markets}

Most empirical research has only focused on firms from some developed countries, such as Japan, U.S. and some European developed countries, however the results from these studies cannot be applied to developing countries (Kuada, 2002) ${ }^{5}$. Australia and China are also neglected in these studies. To fill this gap the present study focuses on Australia and China. The definitions of firm size are adopted from different official definitions in both Australia and China, which will be discussed further below. Size categories using these official definitions are defined for this study. These measurements are expected to provide more reliable results for the studied countries. On the other hand size difference (between these categories) is also adopted in this paper to provide complementary evidence to the results from this study.

\section{Methodology and Research Questions}

Previous literature has suggested that both a qualitative study and a quantitative study are important methods. However, since the early 1980s there has been a fierce debate around which of these is superior (Newman and Benz, 1998). A qualitative study provides industry evidence and rich information on business collaboration, while a quantitative study measures the relationship between the factors and can be used to predict future results. They are complementary research methods (Zhang, 2012). Therefore, this paper has used a quantitative research method to examine the contribution of firm size and size difference to the performance of business collaboration. Qualitative face-to-face interviews are also conducted in Australia and

\footnotetext{
4 Size difference relates to that between the collaborating firms.

${ }^{5}$ See Gulati (1995a), Hagedoorn (1995a), Hagedoorn and Duysters (2002), Hagedoorn and Schakenraad (1994), Kale (1999), Osborn and Baughn (1990), Park and Ungson (1997), Porter (1987) and Shan and Hamilton (1991).
} 
China to verify and provide reliable evidence for the quantitative research results.

\section{Performance Measurement and Results}

Empirical results have shown that both subjective and objective assessments are significant in measuring the performance and results from alliances (Heide and Miner, 1992, Parkhe, 1993b). Therefore, this paper adopts both objective performance and subjective evaluation on the final success rate of business collaboration. A five-point Likert scale is adopted in this study ${ }^{6}$. The objective performance index was calculated from 12 objective measurements, including access to new technology, improved global competitiveness, increased market share, cost savings, assistance in research and development, increased market influence, improved profitability, improved productivity, improved product quality, increased innovations, access to government programs, and allowing participation in the global marketplace ${ }^{7}$. The subjective assessment included the participants' subjective assessments on the success level and fulfillment of expectations (Lin et al., 2009, Saxton, 1997).

\section{Size and Size Difference}

This paper adopted official definitions for firm size used in both Australia and China. In China, firm size is generally measured by the number of employees. The definition for micro enterprises is less than 5 employees, for small enterprises it is 5 to 100 employees, for medium sized enterprises it is 100 to 500 employees, and for large enterprises it is more than 500 employees. In Australia, firm size is also measured by the number of employees. The definition for micro enterprises is less than 5 employees, for small enterprises it is below 20 employees, for medium sized enterprises it is between 20 and 200 employees (for the telecommunication and related industries) and for large enterprises it is more than 200 employees (ABS, 2004, Harvie and Lee, 2003).

Firm size, therefore, is put into six categories according to the official firm size definition in Australia and China: (1) less than 5 employees; (2) 5-19 employees; (3) 20 - 99 employees; (4) 100-199 employees; (5) 200-499 employees; and (6) 500 or more employees. Firms in category 1 are micro sized firms in both Australia and China. Firms in categories 1, 2 and 3 are small sized firms in China; 1 and 2 are small sized firms in Australia. Firms in categories 4 and 5 are medium sized firms in China; 3 and 4 are medium sized firms in Australia. Firms in category 6 are large sized firms in China; and 5 and 6 are large sized firms in Australia.

Size difference is calculated by subtracting the size of the studied firm from the size of its partner. ${ }^{8}$ If the size difference is a negative number then the firm under study has collaborated with a smaller partner. If the size difference is zero it means that the studied firm has

\footnotetext{
${ }^{6}$ Although it is argued that a seven-point scale is better in collecting data, it also increases the complexity level and reduces the response rate. There is a trade-off between these two methods. After discussion with some interviewees during the pilot interviews a five-point Likert scale was used in this study.

7 Arora and Gambardella (1990), Baum, Calabrese and Silverman (2000), Contractor and Lorange (1988), Dyer and Singh (1998), Freeman and Soete (1990), Khanna, Gulati and Nohria (1998), Oliver (1990), Singh and Mitchell (2005), and Wigand and Benjamin (1995).

${ }^{8}$ That is the number of employees of the firm under study is subtracted from the number of employees of the partner.
} 
collaborated with a peer sized firm. If the size difference is a positive number, the firm under study has collaborated with a larger partner. In the quantitative study 10 per cent of the studied firms did not know, or were unsure about, the size of their partners. To keep the data consistent, these firms were categorised into another group indicating missing data for size difference.

\section{Other Variables}

This study uses a composite index for trust calculated from nine measures (subjective trust, risk level, structure similarity, working process similarity, similar goals, industry reputation level of the partner firm, reliability level of the contact person, business networks, and information openness) using a five point Likert-type scale (Adobor, 2005, Barney, 1986, Creed and Miles, 1996, Elg, 2007, Grant, 1996, Gulati, 1995b, Lui and Ngo, 2005, Nooteboom et al., 1997, Ring and Van de Ven, 1994, Saxton, 1997, Zaheer et al., 1998).

Communication is examined by focusing upon three aspects: efficiency, understanding, and proper frequency of communication during business collaboration (Elg, 2007, Olkkonen et al., 2000, Zacharia et al., 2011). Collaboration experience in this study is a calculated value by adding the experiences of the interviewed firm and the partner firm and then dividing by two. Culture similarity in this study is examined using both an objective method (CULTUREOB, a composite measure calculated from the location distance, culture difference, and nationality difference of the collaborating firms) and a subjective view on culture similarity, language similarity, religion similarity, and technological similarity (Kuada, 2002, Shenkar and Zeira, 1987). A five point Likert-type scale is also adopted in the calculation of these measurements.

\section{Research Questions and Hypotheses}

The key research question of this paper is "Does size influence the selection or performance of business collaborations in Australia and China?" If yes, which aspect of the performance does it influence? Size difference is also regarded as one of the key determinants for successful business collaboration (Gulati, 1995a, Saxton, 1997). Does size difference play the same role in business collaboration? Finally, are there any differences in the results for different countries?

To answer these questions, six hypotheses are proposed in this study:

- Hypothesis 1: Size plays a significant role in the objective performance of inter-firm collaboration.

- Hypothesis 2: Size plays a significant role in the subjective outcomes from inter-firm collaboration.

- Hypothesis 3: Size plays a significant role in fulfilling the expectation level of inter-firm collaboration.

- Hypothesis 4: Size difference plays a significant role in the objective performance of inter-firm collaboration.

- Hypothesis 5: Size difference plays a significant role in the subjective outcomes from inter-firm collaboration.

- Hypothesis 6: Size difference plays a significant role in fulfilling the expectation level of inter-firm collaboration.

Results obtained for developed countries could be different to those for developing 
countries (Kuada, 2002). Therefore, the data is first tested in aggregate and then separated into Chinese and Australian groups to examine whether the results are different in different countries. As a five point Likert scale is adopted for measurement of the subjective variables, the performance of business collaboration is also measured using 5 levels forth success rate. Given ordered dependent variables for this statistical analysis, an Ordered Probit analysis method is adopted (Groot and Brink, 2003).

\section{Sample and Data Collection}

The quantitative study was conducted in both Australia and China from May to July 2010. The selected participants were obtained from three sources: (1) the Australian Telecommunications Industry Ombudsman (TIO) lists, (2) the researchers' former business networks, and (3) extension of the researchers' business networks. The selection of sample firms was based on the qualitative study response. An online survey system was developed to make it more convenient for interviewees, break the limitation of location of firms and to enhance the response rate (the response rate of qualitative interviews in Australia is traditionally very low). The questionnaire was compiled from a literature review of previous empirical studies, pilot interviews, qualitative study results, feedback from interviewed managers and industry experience of the researchers. As a result, 339 valid online surveys were collected from both Australia and China, including 239 from China and 100 from Australia, covering micro, small, medium and large firms.

In the qualitative study 7 interviews were conducted in Australia and 24 interviews were conducted in China from October 2008 to January 2009. The selection of cases is purposeful, including all different types of firms in terms of their nationalities, sizes, and industry sectors to provide as much rich information as possible. The selection is also largely dependent on the business networks of the researchers to increase the response rates. The interviewees included CEOs, key managers and senior executives who have good knowledge on collaboration and the development strategy of the firm. The interviews were conducted by the research team who provided a good explanation of the questions, terms and purpose of the study. Suggestions for improvement of the questionnaire were also collected during the interviews. The average length of time for the Chinese interviews was one hour and for Australian interviews it was 20 minutes. The qualitative study provided valuable data, suggestions and support for the quantitative study.

\section{Results and Analysis}

\section{Research Results and Hypotheses Tests}

The quantitative study was conducted in both Australia and China in 2010. Descriptive statistics for the study data for China and Australia are provided in Tables 1 and 2. Table 1 provides a summary of the Chinese interviewed firms, while Table 2 provides a summary of the Australian interviewed firms. Table 3 provides a summary of the 339 completed surveys by firm size in both Australia and China. 


\section{Table 1}

Qualitative Interviews in China

\begin{tabular}{llll}
\hline Basic descriptive statistics & Total interviews: 24 & Total collaborating cases: 45 \\
\hline Size & & & \\
\hline Firm Size & small & medium & large \\
\hline (* based on firm) & 9 & 5 & 10 \\
\hline Size difference & Smaller partner & Peer partner & Larger partner \\
\hline (* based on case $)$ & 5 & 13 & 27 \\
\hline
\end{tabular}

\section{Table 2}

Qualitative Interviews in Australia

\begin{tabular}{lllll}
\hline Basic descriptive statistics & Total interviews: 7 & Total collaborating cases: 8 \\
\hline Size & & & & \\
\hline & Firm Size & Small & Medium & Large \\
\hline (* based on firm) & 1 & 2 & 4 \\
\hline Size difference & Smaller partner & Peer partner & $\begin{array}{l}\text { Larger } \\
\text { partner }\end{array}$ \\
\hline (* based on case $)$ & 0 & 5 & 3 \\
\hline
\end{tabular}

Table 3

Quantitative Surveys in Australia and China

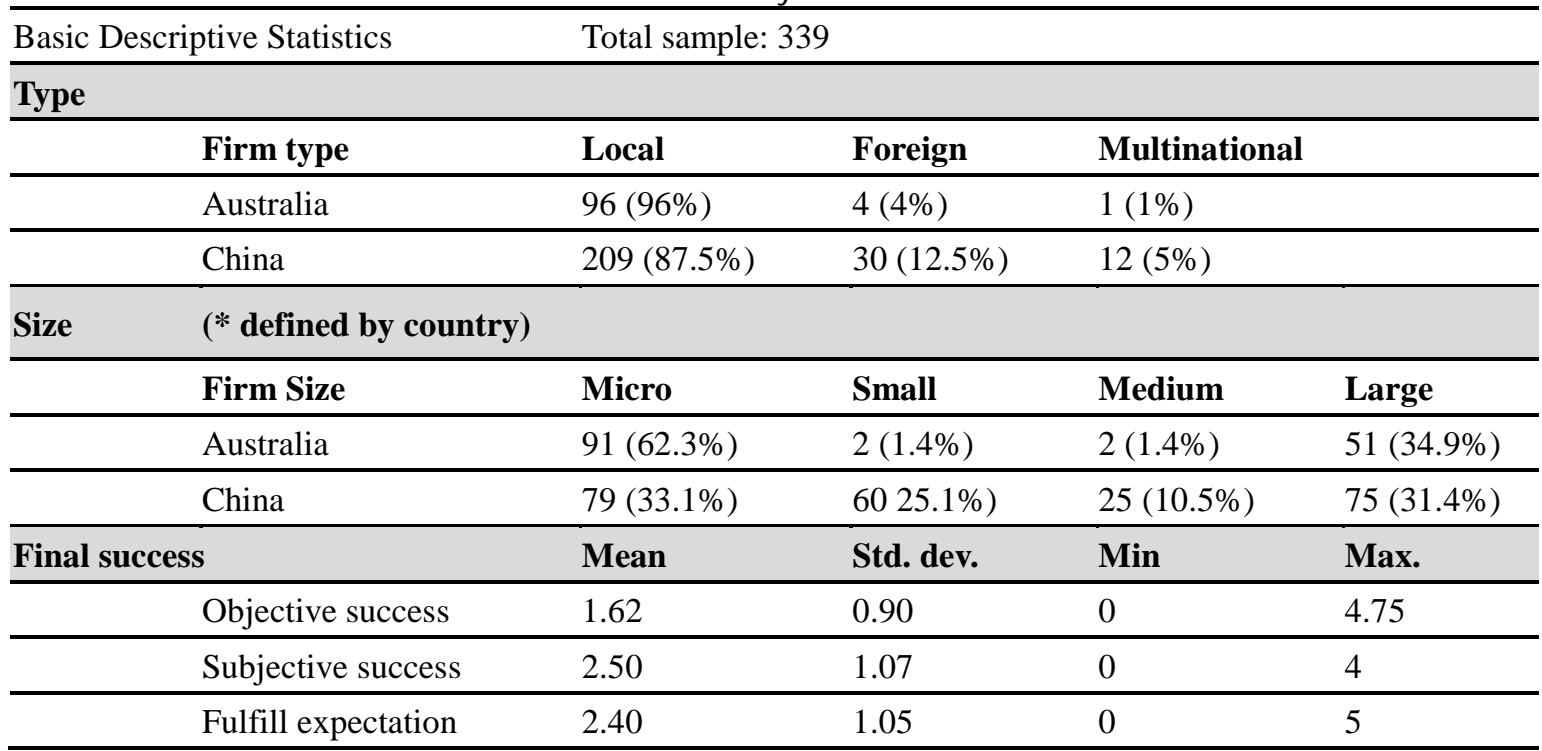


Figure 1

Firm Size Difference from Survey Sample

Size difference in business collaboration

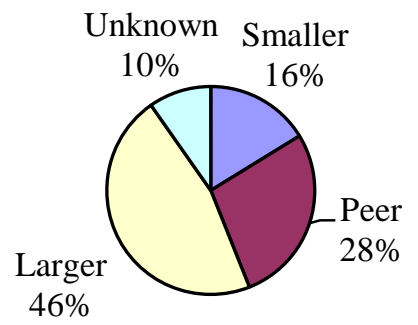

\begin{tabular}{|l}
$\square$ Smaller \\
$\square$ Peer \\
$\square$ Larger \\
$\square$ Unknown
\end{tabular}

Source: Study survey

As shown in Figure 1, 46 per cent of the total firms sampled selected larger-sized business partners as their top business collaborators, 28 per cent of total firms selected peer-sized collaborators and only 16 per cent of total firms sampled selected smaller-sized collaborators in the quantitative study. When separated by country 66 per cent of Chinese firms selected peer and larger sized collaborators, and only 22 per cent of them selected smaller partners. In Australia, 92 per cent of studied firms selected peer or larger sized collaborators and only 3 per cent of them selected smaller partners.

Table 4

Influence of Size on the Performance / Result of Inter-Firm Collaboration

Dependent Variable: FINALSUCCESS

Method: ML - Ordered Probit (Quadratic hill climbing)

Included observations: 339

Number of ordered indicator values: 5

\begin{tabular}{crrrr}
\hline \hline Variable & Coefficient & Std. Error & z-Statistic & \multicolumn{1}{c}{ Prob. } \\
\hline \hline FIRM SIZE & 0.147039 & 0.034347 & 4.281003 & 0.0000 \\
TRUST & 0.089785 & 0.017473 & 5.138541 & 0.0000 \\
COMMUNICATION & 0.230308 & 0.038219 & 6.026061 & 0.0000 \\
EXPERIENCE & -0.050210 & 0.032692 & -1.535823 & 0.1246 \\
CULTURE & -0.057555 & 0.014330 & -4.016405 & 0.0001 \\
\hline \hline Pseudo R-squared & 0.161865 & Akaike info criterion & 2.036494 \\
Schwarz criterion & 2.138069 & Log likelihood & -336.1857 \\
Prob(LR statistic) & 0.000000 & & & \\
\hline \hline
\end{tabular}

This result is also supported by the qualitative interviews. Only 11.1 per cent of the Chinese interviewed firms selected smaller sized firms as their top 5 business partners, while zero percent of Australian interviewed firms selected smaller firms as their top 5 business partners. One interviewed manager from one of the world's top three mobile device producers said: "We only select the top 10 firms in each field to collaborate with to keep our leading position in the world." These results answered the first part of the major research question. Size 
matters when firms choose business collaborators. Firms, either in Australia or China, preferred a larger partner as their top business collaborators. However, do larger business partners bring about a better performance? To answer this question an Ordered Probit analysis is conducted in the quantitative analysis. As shown in Table 4 firm size is significant at all levels to the performance of inter-firm collaboration. Therefore, firm size has a positive and significant influence on the performance of business collaboration.

Table 5 shows the separated results for the different dimensions of collaborating performance. The null hypotheses 1 and 3 are rejected at all levels but null hypothesis 2 cannot be rejected. Therefore, firm size contributes significantly to the objective success level and overall success level but has no significant influence on the subjective success level for business collaborations in this study.

The results are then separated by country to verify the different contributions of firm size in different countries. As shown in Table 6 the country based studies show that size contributed significantly to the objective results (at the 5 per cent level), the subjective success level (at the 1 per cent level) and overall success level (at the 1 per cent level) for China. However, size plays a less important role in Australia, which is only significant to the objective performance of business collaboration. It even has a negative influence on the subjective success rate in Australian business collaboration, although this is not significant. Therefore, the results suggest that firm size plays a very different role in different countries, which answers hypothesis six.

Table 5

Influence of Size on Inter-firm Collaboration at the Aggregate Level

\begin{tabular}{|l|l|l|c|l|}
\hline Dependent Variable & Coefficient of SIZE & Std. Error & t-Statistic & Prob. \\
\hline Objective Success rate & 0.153917 & 0.023070 & 6.671751 & $0.0000 * * *$ \\
\hline Subjective Success rate & 0.032778 & 0.024256 & 1.351336 & 0.1775 \\
\hline Overall Success rate & 0.147039 & 0.034347 & 4.281003 & $0.0000 * * *$ \\
\hline
\end{tabular}

Note: ${ }^{*} \mathrm{p}<0.10,{ }^{* *} \mathrm{p}<0.05,{ }^{* * *} \mathrm{p}<0.01$

Table 6

Influence of Size on Inter-firm Collaboration by Country

\begin{tabular}{|l|l|l|l|l|}
\hline Dependent Variable & $\begin{array}{l}\text { Coefficient of } \\
\text { SIZE }\end{array}$ & Std. Error & t-Statistic & Prob. \\
\hline Objective Success rate (China) & 0.061387 & 0.028090 & 2.185358 & $0.0299^{* *}$ \\
\hline Subjective Success rate (China) & 0.108047 & 0.039473 & 2.737245 & $0.0062^{* * *}$ \\
\hline Overall Success rate (China) & 0.131208 & 0.040303 & 3.255501 & $0.0011^{* * *}$ \\
\hline Objective Success rate (Australia) & 0.315660 & 0.052474 & 6.015549 & $0.0000^{* * *}$ \\
\hline Subjective Success rate (Australia) & -0.039409 & 0.112345 & -0.350788 & 0.7257 \\
\hline Overall Success rate (Australia) & 0.184089 & 0.128261 & 1.435272 & 0.1512 \\
\hline
\end{tabular}

Note: ${ }^{*} \mathrm{p}<0.10,{ }^{* *} \mathrm{p}<0.05,{ }^{* * *} \mathrm{p}<0.01$

As size is used to calculate size difference in this study they are expected to be correlated with each other. Therefore, size difference is now used to replace size in the previous regression analysis. The results are contained in Table 7. Size difference is significant at all levels to the performance of inter-firm collaboration. However, the sign of the coefficient is negative indicating that size difference plays a significant negative role in business collaboration performance. 
Table 7

Influence of Size Difference on Performance/Result of Inter-firm Collaboration

Dependent Variable: FINALSUCCESS

Method: ML - Ordered Probit (Quadratic hill climbing)

Included observations: 339

Number of ordered indicator values: 5

\begin{tabular}{crrrr}
\hline \hline Variable & Coefficient & Std. Error & z-Statistic & Prob. \\
\hline \hline SIZE DIFFERENCE & -0.073267 & 0.020265 & -3.615550 & 0.0003 \\
TRUST & 0.086596 & 0.017385 & 4.981156 & 0.0000 \\
COMMUNICATION & 0.218551 & 0.038084 & 5.738706 & 0.0000 \\
EXPERIENCE & -0.012259 & 0.029915 & -0.409777 & 0.6820 \\
CULTURE & $\underline{-0.060673}$ & 0.014430 & -4.204802 & 0.0000 \\
\hline \hline Pseudo R-squared & 0.155114 & Akaike info criterion & 2.052470 \\
Schwarz criterion & 2.154046 & Log likelihood & -338.8937 \\
Prob(LR statistic) & 0.000000 & & & \\
\hline \hline
\end{tabular}

As shown in Table 8, when the results are separated into the categories of objective and subjective performance, size difference has a significant and negative influence on subjective performance and the overall success rate of business collaborations but has no significant influence on the objective success rate. These results are different from that of the contribution of firm size to business collaboration performance.

Table 8

Influence of Size Difference on Inter-firm Collaboration Performance (Aggregate Results)

\begin{tabular}{|l|l|l|l|l|}
\hline Dependent Variable & $\begin{array}{l}\text { Coefficient of size } \\
\text { difference }\end{array}$ & Std. Error & t-Statistic & Prob. \\
\hline Objective Success rate & -0.016545 & 0.014685 & -1.126646 & 0.2607 \\
\hline Subjective Success rate & -0.05275 & 0.019588 & -2.693019 & $0.0071^{* * *}$ \\
\hline Overall Success rate & -0.073267 & 0.020265 & -3.615550 & $0.0003^{* * *}$ \\
\hline
\end{tabular}

Note: ${ }^{*} \mathrm{p}<0.10,{ }^{* *} \mathrm{p}<0.05,{ }^{* * *} \mathrm{p}<0.01$

As shown in Table 9 the results by individual country show that size difference plays a more important role in business collaboration in China than in Australian. Size difference has a significant negative influence on the subjective performance (at the 5 per cent level) and overall performance (at the 1 per cent level) of business collaboration in China. However, size difference has no significant influence on either the objective or subjective performance of business collaboration in Australia. The results further support that both firm size and size difference play very different roles in business collaborations in different countries. 
Table 9

Influence of Size Difference on Inter-firm Collaboration Performance by Country

\begin{tabular}{|l|l|r|l|l|}
\hline Dependent Variable & $\begin{array}{l}\text { Coefficient } \\
\text { of SIZE }\end{array}$ & \multicolumn{1}{c|}{ Std. Error } & t-Statistic & \multicolumn{1}{l|}{ Prob. } \\
\hline Objective Success rate (China) & -0.018065 & 0.015678 & -1.152220 & 0.2504 \\
\hline Subjective Success rate (China) & -0.050370 & 0.021801 & -2.310483 & $0.0209^{* *}$ \\
\hline Overall Success rate (China) & -0.072271 & 0.022241 & -3.249535 & $0.0012^{* * *}$ \\
\hline Objective Success rate (Australia) & -0.008350 & 0.026822 & -0.311321 & 0.7562 \\
\hline Subjective Success rate (Australia) & -0.068000 & 0.048311 & -1.407526 & 0.1593 \\
\hline Overall Success rate (Australia) & -0.120209 & 0.054244 & -2.216085 & $0.0267 * *$ \\
\hline
\end{tabular}

\section{Examination of the Correlations between the Independent Variables}

Multi-collinearity exists in every equation because it is virtually impossible to find a set of independent variables in the real world that are totally uncorrelated with each other (Studenmund, 2001). To test for multi-collinearity in the correlation coefficients a covariance analysis is conducted by examining the covariance matrix for all the variables. As shown in Table 10 the results do not show a strong correlation between each pair.

Table 10

Covariance matrix

\begin{tabular}{|c|c|c|r|r|c|}
\hline & \multicolumn{1}{|c|}{ SIZE } & \multicolumn{1}{c|}{ TRUST } & COMMU & EXP & CULTURE \\
\hline SIZE & 0.001180 & $5.05 \mathrm{E}-05$ & $5.92 \mathrm{E}-05$ & -0.000515 & $-4.27 \mathrm{E}-05$ \\
\hline TRUST & $5.05 \mathrm{E}-05$ & 0.000305 & -0.000239 & -0.000181 & $-8.49 \mathrm{E}-05$ \\
\hline COMMU & $5.92 \mathrm{E}-05$ & -0.000239 & 0.001461 & $1.80 \mathrm{E}-05$ & $-1.80 \mathrm{E}-05$ \\
\hline EXP & -0.000515 & -0.000181 & $1.80 \mathrm{E}-05$ & 0.001069 & 0.000131 \\
\hline CULTURE & $-4.27 \mathrm{E}-05$ & $-8.49 \mathrm{E}-05$ & $-1.80 \mathrm{E}-05$ & 0.000131 & 0.000205 \\
\hline
\end{tabular}

\section{Implications and Discussion}

The results show that firm size and firm size difference contribute to different aspects of the collaborating performance in Australia and China. Size plays a significantly positive role in business collaboration, implying that bigger firms find it easier to achieve more benefits and more successful business collaboration with others. This is reasonable as big firms usually posses more resources, better technology and access to information and government services. On the other hand, bigger firms usually have a formal process in selecting partners and supervising the process and performance of business collaboration. Therefore, bigger firms usually have better performance in business collaborations than smaller sized firms.

However, size difference plays a negative role in business collaboration, which indicates that collaborating with a bigger partner has a negative influence on the final success rate. Given these conflicting results, firms tend to select bigger sized partners when the initial collaboration relationship was formed. However, the performances of collaborating with bigger sized partners are not as good as expected. Therefore, firms need to pay more attention to peer sized or smaller sized partners rather than bigger sized firms, which may bring them more benefits. This result is also supported by the qualitative interview results. One manager of a small firm, who collaborated with Microsoft, said: "the results varied dramatically when the financial situation 
and strategies of Microsoft changed." To small sized firms it may be a better strategy to collaborate with peer sized partners. It can, therefore, be argued that strategies adopted by some regional governments (in China and Australia or in East Asia more generally) of introducing large multinational firms into their economies would make a limited contribution to the long-run development of local businesses especially if these were predominantly small firms.

Another interesting result from this research is that size and size difference play different roles in the performance of business collaboration in Australia and China. Firm size significantly influenced the objective collaborating performance in Australia. However, in China it influenced more the subjective performance of collaboration. Cultural differences and different recognition of firm size could be one explanation for these results. Small sized firms are respected as driving innovation and regional economic growth in Australia. However, large sized firms are usually appreciated and supported by local governments (Naughton, 2006). Therefore, different business environments, cultural backgrounds, and definitions of firm size should be considered before using firm size as a factor in empirical studies.

There are some limitations of this study. The first one is sample selection which focuses on the telecommunications and related industries. This is because different industries may have different definitions of firm size. The second implication is the study questionnaire which is designed for Australia and China. Future research could expand the research range to include more countries and industries. However, it can be argued that the definition of firm size should be changed if more countries or industries are introduced.

\section{Conclusions}

Instead of adopting previous definitions of firm size this paper has developed size categories by using official definitions of firm size used in the countries studied.

Both qualitative and quantitative studies have shown that firms prefer larger-sized partners as their top business collaborators. However, the results from this study show that collaborating with bigger firms has a negative influence on collaborating performance. Firms prefer bigger collaborators because these partners usually have better resources, technologies, and financial supports, which will bring intangible benefits to their partners during collaboration. Furthermore, the tangible revenues from these collaborations are much higher. However, collaborating with bigger firms is more risky as these partners usually have more choices when choosing business partners. The results imply that it would be a better strategy to collaborate with a peer sized partner.

Size and size difference contributed to different parts of business collaboration in Australia and China. Firm size only influences the objective results in Australia but influences more subjective results in China. Firm size plays a different role in different countries. Size difference, on the other hand, plays a more important role for business collaborations in China but not in Australia. Therefore, different business environments, culture backgrounds, and definitions of firm size should be considered when policies and programs are designed to support domestic or international business collaboration. 


\section{References}

ABS 2004. Definition of small business. Australian Bureau of Statistics.

Adobor, H. 2005. Optimal trust? Uncertainty as a determinant and limit to trust in inter-firm alliance. Leadership \& Organization Development Journal, 27, 537-53. http://dx.doi.org/10.1108/01437730610692407

Agardi, I. A. B., A. 2008. The moderator role of size in alliance performance relationships. ACTA Oeconomica, 58, 185-99. http://dx.doi.org/10.1556/AOecon.58.2008.2.3

Arora, A. \& Gambardella, A. 1990. Complementarity and external linkages: the strategics of the large firms in biotechnology. Journal of Industrial Economics, 38, 361-79. http://dx.doi.org/10.2307/2098345

Barney, J. B. 1986. Strategic factor markets: Expectations, luck and business strategy. Management Science, 42, 1231-41. http://dx.doi.org/10.1287/mnsc.32.10.1231

Barney, J. B. 2001. Is the resource-based 'view' a useful perspective for strategic management research? Yes. Academy of Management Review, 26, 41-56.

Baum, J., Calabrese, T. \& Silverman, B. B. 2000. Don't go it alone: alliance network composition and startup's performance in Canadian biotechnology. Strategic Management Journal, 21, 267-94 http://dx.doi.org/10.1002/(SICI)1097-0266(200003)21:3<267::AID-SMJ89>3.0.CO;2-8

Berg, S. V., Duncan, J. \& Friedman, P. 1982. Joint Venture Strategies and Corporate Innovation, Cambridge, Oelgeschlager, Gunn and Hain.

Burgers, W. P., Hill, C. \& Kim, W. C. 1993. A theory of global strategic alliances: The case of the global auto industry. Strategic Management Journal, 14, 419-32. http://dx.doi.org/10.1002/smj.4250140603

Chandler, A. D. 1962. Strategy and structure: Chapters in the history of the industrial enterprise, Cambridge, MA, MIT Press.

Chung, Q. B., Luo, W. \& Wagner, W. P. 2006. Strategic alliance of small firms in knowledge industries A management consulting perspective. Business Process Management Journal, 12, 206-233. http://dx.doi.org/10.1108/14637150610657549

Coase, R. H. 1937. The Nature of the Firm. Economics, 4, 386-405.

Contractor, F. J. \& Lorange, P. 1988. Cooperative Strategies in International Business Canada, Lexington Books

Creed, W. E. D. \& Miles, R. E. 1996. Trust in Organizations. In: Kramer, R. M. \& Tyler, T. R. (eds.) Trust in Organizations: Frontiers of Theory and Research. New Delhi: Sage Publications. http://dx.doi.org/10.4135/9781452243610.n2

Das, T. K. \& Teng, B. S. 1998. Between trust and control: developing confidence in partner cooperation in alliances. Academy of Management Review, 23, 491-512.

Dyer, J. H. \& Singh, H. 1998. The relational review: cooperative strategy and sources of interorganizational competitive advantage. Academy of Management Review, 23, 660-679.

Elg, U. 2007. Market Orientation as Inter-firm Cooperation: An International Study of the Grocery Sector. European Management Journal, 25, 283-97. http://dx.doi.org/10.1016/j.emj.2007.03.001

Felzensztein, C. \& Gimmon, E. 2007. The influence of culture and size upon inter-firm marketing cooperation A case study of the salmon farming industry. Marketing Intelligence \& Planning, 25, 377-93. http://dx.doi.org/10.1108/02634500710754600

Freeman, C. \& Soete, L. 1990. New Explorations in the Economics of Technical Change, London and New York, Pinter Publisher.

Grant, R. M. 1996. Toward a Knowledge-based Theory of the Firm. Strategic Management Journal, 17, 109-22.

Groot, W. \& Brink, H. M. 2003. Firm-related training tracks: a random effects ordered probit model. Economics of Education Review, 22, 581-9. http://dx.doi.org/10.1016/S0272-7757(03)00030-X

Gulati, R. 1995a. Social structure and alliance formation patterns: a longitudinal analysis. Administrative Science Quarterly, 40, 619-52. http://dx.doi.org/10.2307/2393756

Gulati, R. 1995b. Does familiarity breed trust? The implications of repeated ties for contractual choice in alliances. Academy of Management Journal, 38, 85-112. http://dx.doi.org/10.2307/256729

Hagedoorn, J. 1995a. Research notes and communications a note on international market. Strategic Management Journal 16, 241. http://dx.doi.org/10.1002/smj.4250160307

Hagedoorn, J. 1995b. A note on international market leaders and networks of strategic technology partnering. Strategic Management Journal, 16, 241-250. http://dx.doi.org/10.1002/smj.4250160307

Hagedoorn, J. \& Duysters, G. 2002. External sources of innovative capabilities: the preference for strategic alliances or mergers and acquisitions. Journal of Management Studies, 39, 167-88.

http://dx.doi.org/10.1111/1467-6486.00287 
Hagedoorn, J. \& Schakenraad, J. 1994. The effect of strategic technology alliances in information technologies. Strategic Management Journal, 15, 291-309. http://dx.doi.org/10.1002/smj.4250150404

Harvie, C. \& Lee, B. C. 2003. Public Policy and SME Development. Economics Working Paper Series 2003. University of Wollongong.

Heide, J. B. \& Miner, A. S. 1992. The Shadow of the Future: Effects of Anticipated Interaction and Frequency of Contact on Buyer-Seller Cooperation. Academy of Management Journal, 35, 265. http://dx.doi.org/10.2307/256374

Jaouen, A. \& Gundolf, K. 2007. Strategic alliance between microfirms specific patterns in the French context. International Journal of Entrepreneurial Behaviour \& Research, 15, 48-70. http://dx.doi.org/10.1108/13552550910934459

Kale, P. 1999. Alliance capability \& success: a knowledge-based approach. a dissertation in management. University of Pennsylvania.

Khanna, T., Gulati, R. \& Nohria, N. 1998. The dynamics of learning alliances: competition, cooperation and relative scope. Strategic Management Journal, 19, 193-210. http://dx.doi.org/10.1002/(SICI)1097-0266(199803)19:3<193::AID-SMJ949>3.0.CO;2-C

Kuada, J. 2002. Collaboration between developed and developing country-based firms: Danish-Ghanaian experience. The journal of Business and Industrial marketing, 17, 538. http://dx.doi.org/10.1108/08858620210442866

Lin, Z., Yang, H. \& Arya, B. 2009. Alliance partners and firm performance: resource complementarity and status association. Strategic Management Journal, 30, 921-40. http://dx.doi.org/10.1002/smj.773

Lui, S. S. \& Ngo, H. Y. 2005. An Action Pattern Model of Inter-firm Cooperation. Journal of Management Studies, 42, 0022-2380.

Naughton, B. 2006. The Chinese Economy: Transitions and Growth, The MIT Press.

Newman, I. \& Benz, C. R. 1998. Qualitative-quantitative research methodology: exploring the interactive continuum, Southern Illinois University, U.S.A, Board of Trustees.

Nooteboom, B., Berger, H. \& Noorderhaven, N. G. 1997. Effects of trust and governance on relational risk. Academy of Management Journal, Briarcliff Manor, 40, 308.

Oliver, C. 1990. Determinants of interorganizational relationships: integration and future directions. Academy of Management Review, 15, 241-65.

Olkkonen, R., Tikkanen, H. \& Alajoutsijärvi, K. 2000. The Role of Communication in Business Relationships and Networks. Management Decision, 38, 403-409. http://dx.doi.org/10.1108/EUM0000000005365

Osborn, R. N. \& Baughn, C. C. 1990. Forms of interorganizational governance for multinational alliances. Academy of Management Journal, 33, 503-19. http://dx.doi.org/10.2307/256578

Oxley, J. E. 1997. Appropriability hazards and governance in strategic alliances: a transaction cost approach. Journal of Law, Economics, and Organization 13, 387-409. http://dx.doi.org/10.1093/oxfordjournals.jleo.a023389

Papadopoulos, A., Cimon, Y. \& Hebert, L. 2008. Asymmetry, heterogeneity and inter-firm relationships Organizing the theoretical landscape. International Journal of Organizational Analysis, 16, 152-65. http://dx.doi.org/10.1108/19348830810915541

Park, S. H. \& Ungson, G. R. 1997. The effect of national culture, organizational complementarity and economic motivation on joint venture dissolution. Academy of Management Journal, 40, 279-307. http://dx.doi.org/10.2307/256884

Parkhe, A. 1993b. Strategic alliance structuring: A game theoretic and transaction cost examination of inter-firm cooperation. Academy of Management Journal, 36, 794-829. http://dx.doi.org/10.2307/256759

Porter, M. E. 1987. From competitive strategy to cooperative strategy. Harvard Business Review, 65, 43-59.

Porter, M. E. 1990. New Global Strategies for Competitive Advantage. Planning Review, 18, 4. http://dx.doi.org/10.1108/eb054287

Ring, P. \& Van De Ven, A. 1994. Developmental processes of cooperative inter-organizational relationships. Academy of Management Review, 19, 90-118.

Rumelt, R. P. 1974. Strategy, structure, and economic performance, Cambridge, MA, Harvard university Press.

Rumelt, R. P. 1984. Towards a Strategic Theory of the Firm, New Jersey, Englewood Cliffs.

Rumelt, R. P. 1991. How Much does Industry Matter? Strategic Management Journal, 12, 167-85. http://dx.doi.org/10.1002/smj.4250120302

Saxton, T. 1997. The effects of partner and relationship characteristics on alliance outcomes. Academy of Management Journal, 40, 443-61. http://dx.doi.org/10.2307/256890

Shan, W. \& Hamilton, W. 1991. Country-specific advantage and international cooperation. Strategic Management Journal, 12, 419-32. http://dx.doi.org/10.1002/smj.4250120603 
Shenkar, O. \& Zeira, Y. 1987. Human resources management in international joint ventures: Directions for research. Academy of Management Review, 12, 546-57.

Singh, K. \& Mitchell, W. 2005. Growth dynamics: The bidirectional relationship between interfirm collaboration and business sales in entrant and incumbent alliances. Strategic Management Journal, 26, 497-521. http://dx.doi.org/10.1002/smj.462

Studenmund, A. H. 2001. Using Econometrics a practical guide, 4th ed, Addison Wesley.

Tallman, S. 2000. Forming and Managing Shared Organization Ventures - Resources and Transaction costs. In: Faulkner, D. O. \& Rond, M. D. (eds.) Cooperative Strategy. New York: Oxford University Press.

Teece, D. J. 1977. Technological transfer by multinational firms: The resource cost of international technological transfer. Economic Journal, 87, 242-61. http://dx.doi.org/10.2307/2232084

Teece, D. J. 1982. Towards an economic theory of the multiproduct firm. Journal of Economic Behavior and Organization, 3, 39-63. http://dx.doi.org/10.1016/0167-2681(82)90003-8

Teece, D. J. 1986. Profiting from technological innovation: Implications for integration, collaboration, licensing, and public policy. Research Policy, 15, 285-305. http://dx.doi.org/10.1016/0048-7333(86)90027-2

Wigand, R. T. \& Benjamin, R. I. 1995. Electronic Commerce: Effects on Electronic Markets. Journal of Computer Mediated Communication, 1, 28-32.

Zacharia, Z. G., Nix, N. W. \& Lusch, R. F. 2011. Capabilities that enhance outcomes of an episodic supply chain collaboration. Journal of Operations Management, 29, 591-603. http://dx.doi.org/10.1016/j.jom.2011.02.001

Zaheer, A., Mcevily, B. \& Perrone, V. 1998. Does trust matter? Exploring the effects of interorganizational and interpersonal trust on performance. Organization Science, 9, 141-59. http://dx.doi.org/10.1287/orsc.9.2.141

Zhang, Y. 2012. An analysis of collaboration in the Australian and Chinese mobile telecommunication markets. Doctor of Philosophy (Economics), University of Wollongong. 